\title{
Observations of mixed-species bird flocks at Kichwa Tembo Camp, Kenya
}

\author{
Alasdair I V Gordon and Nancy M Harrison
}

\author{
Alasdair I V Gordon \\ Anglia Ruskin University \\ East Road \\ Cambridge CB1 1PT \\ UK \\ e-mail: aligee75@yahoo.co.uk
}

Corresponding author and contact details:

Nancy M Harrison

Anglia Ruskin University

East Road

Cambridge CB1 1PT

UK

e-mail: nancy.harrison@anglia.ac.uk

Telephone: 08451962524 


\begin{abstract}
Mixed-species foraging flocks were studied at Kichwa Tembo Camp on the edge the Masia Mara National Reserve in Kenya between July and September 2004. Observations were made on 29 mixed-species flocks, in which 24 species participated. African Paradise Flycatcher Terpsiphone viridis, Black-backed Puffback Dryoscopus cubla, Grey-backed Cameroptera Camaroptera brachyura, Collard Sunbird Hedydipna collaris and Cabanis's Greenbul Phyllastrephus cabanisi were the most common participants in mixed-species flocks, as well as among the most frequently encountered bird species overall. The Black-backed Puffback was identified as the nuclear species in flocks due to their abundance and frequency with which they were followed by other species. Mixed-species flocks represent another niche dimension in this diverse bird community, but few of these species could be described as flock specialists; most of the birds observed in mixed-species flocks in this study were opportunistic attendant species, including the African Pygmy Kingfisher Ispidina picta, not previously described as joining mixed-species flocks.
\end{abstract}




\section{Introduction}

Mixed-species flocks of insectivorous birds are a conspicuous feature of tropical communities worldwide (Rand 1954, Moynihan 1960, Jones 1977, Powell 1979, Wiley 1980), important in structuring avian communities of African forests (Chapin 1932, Vernon 1980), but also evident in open woodland and savannah habitats (GreigSmith 1978a, Thomson and Ferguson 2007). The high diversity of bird species observed in the tropics has been attributed to the increased number of niches and tighter niche packing (Weins 1989). Tropical species tend to use a narrow range of habitats (Karr 1971, Lovejoy 1974), and may be more specialized in their foraging behaviour (Terborgh and Weske 1969, Stiles 1978) than their temperate counterparts. However comparisons of the feeding behaviour of birds in mixed-species flocks, and apart from them, have found a tendency for species to converge in feeding niches, opposite to the expectation if competition is forcing niche segregation (Hino 1998, Thomson and Ferguson 2007).

Mixed-species foraging flocks are remarkably coherent structures, often involving the same individuals of a small number of species foraging over a well-defined common home range (Greig-Smith 1978a, Munn and Terborgh 1979). The attachment of species to flocks varies, with some species unambiguously flock specialists, whereas many others are ephemeral, opportunistic participants. Typically flocks have identifiable 'nuclear' species which attract birds of other species and are instrumental in the initiation and maintenance of mixed-species feeding flocks (Winterbottom 1949, Rand 1954, Moynihan 1960, Gram 1998). The adaptive value of mixed flocking has usually been attributed to anti-predator effects, aids to foraging, or both (Rand 1954, Morse 1970, Buskirk 1976, Croxall 1976, Diamond 1987, Thomson and Ferguson 2007).

This study aimed to describe the membership of the mixed-species flocks in the context of the local diversity of birds at Kichwa Tembo Camp, Kenya. Behavioural observations were made in order to evaluate foraging strategies within mixed-species flocks and the nature of inter-specific relationships. 


\section{Methods}

The study was carried out at Kichwa Tembo Camp between mid July and mid

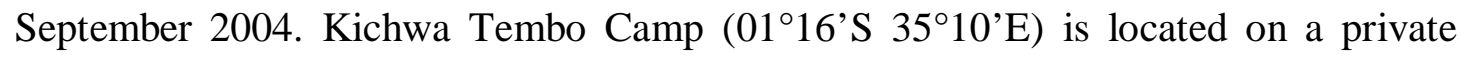
concession leased from Maasai landlords. The camp is set in the fringe of a riverine forest at the foot of the Oloololo Escarpment on the western border of the Masai Mara Reserve. The riverine forest occurs in the camp, due to the perennial Sabaringo River and the protection the vegetation gains from the surrounding electric fence. The climate is temperate with average temperatures of $26^{\circ} \mathrm{C}$ during the day and $12^{\circ} \mathrm{C}$ during the night. Little rain fell during the study period as it was between the 'long rains' in April and May and the 'short rains' in November. The altitude of the camp is 1634m above sea level (CCAfrica 2005).

Observations were made of mixed-species flocks between the $16^{\text {th }}$ July and the $12^{\text {th }}$ of September 2004. A bird was defined to be a member of a mixed-species flock if part of a cluster of three or more birds moving together, maintaining the distance among themselves and preserving discontinuity between areas with and without birds (Berner \& Grubb 1985). Once encountered, a flock was followed until birds had dispersed, or contact was lost. Only flocks that met the definition without any ambiguity were followed. Data were collected on foraging behaviour and species composition. Five types of foraging techniques were recorded (following Eguchi et al 1993): gleaning, hovering (i.e. catching sedentary prey during the hover), probing, snatching (i.e. jumping upon sedentary prey and snatching it off) and hawking (i.e. flycatching aerial prey). Five categories of the foraging location were recognized: leaf, twig, branch, trunk, air and undergrowth.

Species diversity was quantified using the X-species (McKinnon) lists method. The observer recorded each new species occurrence until he reached a target number of species. The number of species recorded in the list is related to the richness of the local avifauna, and thus for riverine/montane forests of Africa 15-species lists were appropriate (McKinnon \& Phillips 1993). Evaluating relative abundance using this method is problematic because of the markedly different detectability of species, but the method is a means of characterising the composition of the avian community and was used in this way to show the context of mixed-species flocks. Observations of mixed-species flocks were made independently of the 15 -species lists. 
Cole's (1949) coefficient of association (CA) was calculated in order to examine whether the degree of attendance of a given species in a mixed-species flock was influenced by the presence of other species. Thus, $C A=(a d-b c) /[(a+b)(c+d)]$. The variables are the number of flocks in which both species $A$ and $B$ are present $(a)$, only species $A$ is present $(b)$, only species $B$ is present $(c)$, neither species is present (d). Significance in the associations was established using Chi-squared test $(\alpha=$ $0.05)$.

\section{Results}

Observations were made of 29 mixed-species foraging flocks with a total of 24 different bird species participating, a total of 384 individual birds. African Paradise Flycatcher Terpsiphone viridis, Black-backed Puffback Dryoscopus cubla, Greybacked Camaroptera Camaroptera brachyura, Collard Sunbird Hedydipna collaris and Cabanis's Greenbul Phyllastrephus cabanisi were seen in more than half of the observed flocks (Table 1). Most of the bird species were observed in a low proportion of the mixed-species flocks. The average flock size was 13.2 birds, which consisted of 5.83 species per flock (range 2-13) with an average of 2.3 birds per species per flock. Most species were represented in a flock by a single individual, or by a pair, however for the Black-backed Puffback and the Cabanis's Greenbul there was a mean number of over 3.5 individual birds per flock.

Independently of the observations of mixed-species flocks, a total of 7915 -species McKinnon lists were made over the two month study period, in which 1185 birds of a total of 111 different species were observed (Appendix 1). Some species such as the Common Bulbul Pycnonotus barbatus and the African Paradise Flycatcher were recorded in over $60 \%$ of the lists, while many more species were only rarely encountered. Of the 111 species recorded, 18 species were recorded on only one list and 12 species were recorded on only two lists. The four most common participants in mixed-species flocks (African Paradise Flycatcher, Black-backed Puffback, Greybacked Cameroptera and Collard Sunbird) were also among the 7 most frequently recorded species in the McKinnon lists. 
The frequency with which the 6 most regular flock participants co-occurred in flocks was scored and Cole's Association Coefficient (Cole 1949) was calculated (Table 2). Fourteen of the fifteen correlations among species pairs were significant. The Blackback Puffback and Cabanis's Greenbul were significantly positively associated with all six of the other species common in flocks.

The foraging technique and foraging location in vegetation among the five most common participants in mixed-species flocks at Kichwa Tembo was compared (Fig 1 and Fig 2). The African Paradise Flycatcher was recorded using hawking $74 \%$ of the time as its predominant foraging technique; it was the principal aerial predator among the flock participants. The Grey-backed Cameroptera and Cabanis's Greenbul were seen to snatch their prey over $60 \%$ of the time. They were also the only species to forage largely in the undergrowth. The Collard Sunbird was recorded to forage $77 \%$ of the time by means of gleaning; their preferred foraging location was on the leaves. The Black-backed Puffback used a wide range of foraging techniques and also varied greatly with regards to foraging location within the vegetation.

\section{Discussion}

The African Paradise Flycatcher, Black-backed Puffback, Grey-backed Cameroptera and Collard Sunbird were the four most common mixed-species flock participants, as well as being among the most frequently encountered bird species overall at Kichwa Tembo Camp. These and many of the other participants were as frequently observed apart from mixed-species flocks as in them, a pattern consistent with other reports in which $50 \%$ or fewer of the individuals from participating species were found to be active in flocks at any given time (e.g. McClure 1967, Powell 1985). Large flocks contained similar numbers of each species as did small flocks (usually one or two), and appeared to grow in size as the result of more species joining, similar to GreigSmiths (1978a) findings in Ghana.

Birds described as 'nuclear species' can be recognized by the regularity of their occurrence in flocks, their position in the front of the flock, or the frequency with which they were followed by other species (Winterbottom 1949, Davis 1946, Moynihan 1960, Morse 1970). The most likely candidate which appears to fulfil these requirements is the Black-backed Puffback, which was positively associated with all of the common flock participants. The Black-backed Puffback has several 
characteristics which might stimulate following-reactions by other birds: the birds are active, continually moving from perch to perch; they habitually travel in small parties, which might be expected to provide a stronger stimulus than single birds; their calls are loud and distinctive, and might be an effective signal in the relative poor visibility of the riverine forest. Greig-Smith (1978a) identified White-winged Black Tit Parus leucomelas as the 'nucleus' species in savannah woodland in Ghana for similar reasons. Through their behaviour Black-backed Puffbacks appear to stimulate positive association, and have been documented as well by Vernon (1980) as forming positive associations with a different suite of species found in Brachystegia woodland.

Mixed-species flocks typically coalesce in times of scarcity - the dry season in many tropical regions (Salewski et al. 2003, Croxall 1976) - and flocks may be of benefit both in location of widely dispersed resources, and also in the enhanced security of flock membership when travelling over unknown territory (Buskirk 1976). Protection from predators, when required to search across larger areas is another likely benefit, which explains the many occasional participants. Other foraging advantages are possibly leading birds to join mixed-species flocks at Kichwa Tembo, such as more efficient foraging as the result of the 'beater effect' (Moynihan 1960, Diamond 1987, Hino 1998, Thomson and Ferguson 2007), increased access to resources defended by territorial birds (Moynihan 1960, Diamond 1987), and shared information about the location of food (Krebs 1973, Greig-Smith 1978b).

The 'beater effect' is a convincing benefit for some participants; notably African Paradise Flycatchers would follow other birds, mostly Black-backed Puffbacks, and forage on the insects flushed by these birds. Rand (1936), Croxall (1976), MacDonald and Henderson (1977) also found species highly similar in their behaviour to Paradise Flycatchers catching insects flushed from substrates by the gleaners and snatchers.

One of the mixed-species flocks observed at Kichwa Tembo included an African Pygmy-kingfisher Ispidina picta, not previously recorded with such flocks, but documented following columns of driver ants to catch fleeing insects (del Hoyo et al. 2001); bird parties are found following driver ants which are superficially similar but unrelated to mixed-species flocks of birds (Chapin 1932). The African Pygmykingfisher was observed following a large flock that was moving through riverine forest not far from the Sabaringo River. It would sit on a low perch scanning the ground for prey, occasionally head-bobbing or tail-flicking. It would dart into the 
undergrowth (forest debris) seizing prey and return to a perch where prey would be swallowed whole, before catching up with the flock again. This particular mixedspecies flock was successfully tracked for $45 \mathrm{~min}$ travelling a distance of about $150 \mathrm{~m}$.

Mixed-species flocks at Kichwa Tembo were dominated by opportunistic attendant species, and it is unlikely that any simple explanation is sufficient to account for the flock membership of all species (Wiley 1971, MacDonald \& Henderson 1977, GreigSmith 1978a, Powell 1985). The advantages in terms of predator detection and avoidance are likely to be an important reason a great many species are seen to join flocks fleetingly. These observations differed from those of Thomson and Ferguson (2007) in that relatively few of the participants were hawking for insects. The gleaning and probing behaviours commonly observed, and the activity in the undergrowth may have made these birds particularly vulnerable to predators, and the participation in the flocks would have offered some protection through both increased vigilance offered by some of the less vulnerable group members, and through the dilution effect.

Once birds converge into mixed-species flocks, each species is likely to benefit in its own way from the foraging opportunities which come from the aggregation (Vernon 1980). For opportunist species joining, such as the African Pygmy-kingfisher there is likely to be foraging benefits through the beater effect. The advantages from predator detection and foraging are not mutually exclusive and it is likely both represent selective pressures favouring opportunistic participation, with a differing balance important for different species, or perhaps at different times. A large variety of species were observed as occasional participants, and the selective pressures that have shaped their propensity to join mixed-species flocks must be various (Morse 1970, Buskirk 1976). For the six species at the heart of the flocks, they were also often seen apart, and none of the birds appeared to be obligate participants as documented elsewhere in the tropics. 


\section{Acknowledgements}

This project would not have been possible if it was not for the financial assistance from the Anglia Foundation Scholarship Trust, and the encouragement and support of friends and family. We thank Mick Whitehouse and two unknown reviewers for their assistance in improving the manuscript. We are also grateful to CCAfrica for their hospitality, especially Debra Fox, Theresa Pereira, the Kichwa Tembo management team and all the staff in the camp. 


\section{References}

Berner TO and Grubb TC Jr 1985. An experimental analysis of mixed-species flocking in birds of decidous woodland. Ecology 66: 1229-1236

Buskirk RE 1976. Social systems in a tropical forest avifauna. American Naturalist 110: 293-310.

CCAfrica 2005. (Conservation Corporation Africa), Kichwa Tembo, Kenya. www.ccafrica.com/reserve-1-id-2-11

Chapin JP 1932. The Birds of the Belgian Congo. Part I Bulletin of the American Museum of Natural History 75: 256 pp.

Cole L 1949. The measure of interspecific association. Ecology 30: 411-424

Croxall JP 1976. The composition and behaviour of some mixed-species bird flocks in Sarawak. Ibis 118: 333-346

Davis DE 1946. A seasonal analysis of mixed flocks of birds in Brazil. Ecology 27: $168-181$

del Hoyo J, Elliott A and Sargatal T 2001. Handbook of Birds of the World, Vol. 6. Lynx Edicions and BirdLife International

Diamond J 1987. Flocks of brown and black New Guinean birds: a bicoloured mixed-species foraging association. Emu 87: 2001-2011

Eguchi K, Yamagishi S and Randrianasolo V 1993. The composition and foraging behaviour of mixed-species flocks of forest-living birds in Madagascar. Ibis 135: 9196

Gram WK 1998. Winter participation by Neotropical migrant and resident birds in mixed-species flocks in northeastern Mexico. Condor 100: 44-53

Greig-Smith PW 1978a. The Formation, Structure and Function of Mixed-Species Insectivorous Bird Flocks in West African Savanna Woodland. Ibis 120: 284-295

Greig-Smith PW 1978b. Imitative foraging in mixed-species flocks of Seychelles birds. Ibis 120: 233-235

Hino T 1998. Mutualistic and ocmmensal organization of avian mixed-species floraging flocks in a forest of western Madagascar. Journal of Avian Biology 29: 1724

Jones SE 1977. Coexistence in mixed species antwren flocks. Oikos 29: 366-375

Karr JR 1971. Structure of avian communities is selected Panama and Illinois habitats. Ecological. Monographs 41: 207-233

Krebs JR 1973. Social learning and the significance of mixed-species flocks of chickadee (Parus spp.). Canadian Journal of Zoology 51: 1275-1288 
Lovejoy TE 1974. Bird diversity and abundance in Amazon forest communities. Living Bird 13: 127-191

MacDonald DW and Henderson DG 1977. Aspects of the behaviour and ecology of mixed-species bird flocks in Kashmir. Ibis 119: 481-493

McClure HE 1967. The composition of mixed-species flocks in lowland and submontane forests of Malaya. Wilson Bulletin 79: 131-154

McKinnon J and Phillips K 1993. A Field Guide to the Birds of Borneo, Sumatra, Java and Bali. Oxford University Press, Oxford

Morse DH 1970. Ecological aspects of some mixed-species foraging flocks of birds. Ecological Monographs 40: 119-168

Moynihan M 1960. Some adaptations which help to promote gregariousness. Proceedings of the 12th International Ornithological Congress (1958): 523-541

Munn CA and Terborgh JW 1979. Multi-species territoriality in Neotropical foraging flocks. Condor 81: 338-347

Powell GVN 1979. Structure and dynamics of interspecific flocks in a Neotropical mid-elevation forest. Auk 96: 375-390

Powell GVN 1985. Sociobiology and adaptive significance of interspecific foraging flocks in the neotropics. Ornithological Monogrphs. 36: 713-732

Rand AL 1936. The distribution and habits of Madagascar birds. Bulletin of the American Museum of Natural History 72: 143-499

Rand AL 1954. Social feeding behavior of birds. Fieldiana: Zoology 36: $71 \mathrm{pp}$.

Salewski V, Bairlein F and Leisler B 2003. Niche partitioning of two Palearctic passerine migrants with Afrotropical residents in their West African winter quarters. Behavioural Ecology 14: 493-502

Stiles EW 1978. Avian communities in temperate and tropical alder forest. Condor 80: $276-284$

Terborgh JW and Weske JS 1969. Colonization of secondary habitats by Peruvian birds. Ecology 50: 765-782

Thompson RL and Ferguson JWH 2007. Composition and foraging behaviour of mixed-species flocks in two adjacent African woodland habitats: a spatial and temporal perspective. Ostrich 78: 65-73

Vernon CJ 1980. Bird parties in central and South Africa, pp 313-325 in Proceedings of the IV Pan-African Ornithological Congress. Johannesburg: SAOS

Weins JA 1989. The Ecology of Bird Communities. Cambridge: Cambridge University Press

Wiley RH 1971. Cooperative roles in mixed flocks of antwrens (Formicariidae). Auk 88: $881-892$ 
Wiley RH 1980. Multi-species antbird societies in lowland forest of Surinam and Ecuador: stable membership and foraging differences. Journal of Zoology 191: 127145

Winterbottom JM 1949. Mixed bird parties in the tropics, with special reference to Northern Rhodesia. Auk 66: 258-263. 
Table 1: Composition of mixed-species bird flocks at Kichwa Tembo.

\begin{tabular}{|l|c|c|c|}
\hline \multicolumn{1}{|c}{ Species } & \multicolumn{2}{c}{$\begin{array}{c}\text { Flocks } \\
\text { joined }\end{array}$} & \multicolumn{2}{c|}{$\begin{array}{c}\text { Flock } \\
\text { attendance }\end{array}$} \\
\hline African Paradise Flycatcher Terpsiphone viridis & 26 & $89.7 \%$ & 1.8 \\
\hline Black-backed Puffback Dryoscopus cubla & 22 & $75.8 \%$ & 3.8 \\
\hline Grey-backed Camaroptera Camaroptera brachyuran & 17 & $58.6 \%$ & 1.9 \\
\hline Collard Sunbird Hedydipna collaris & 17 & $58.6 \%$ & 2.5 \\
\hline Cabanis's Greenbul Phyllastrephus cabanisi & 15 & $51.7 \%$ & 3.5 \\
\hline Common (Brown-throated) Wattle-eye Platysteira cayanea & 13 & $44.8 \%$ & 2.0 \\
\hline Yellow White-eye Zosterops senegalensis & 9 & $31.0 \%$ & 2.7 \\
\hline Common Bulbul Pycnonotus barbatus & 7 & $24.1 \%$ & 1.9 \\
\hline Black Cuckoo-shrike Campephaga flava & 7 & $24.1 \%$ & 1.0 \\
\hline Yellow-rumped Tinkerbird Pogoniulus bilineatus & 5 & $17.2 \%$ & 1.0 \\
\hline Tropical Boubou Laniarius aethiopicus & 3 & $10.3 \%$ & 1.3 \\
\hline Spectacled Weaver Ploceus ocularis & 3 & $10.3 \%$ & 1.3 \\
\hline Grey-capped Warbler Eminia lepida & 3 & $10.3 \%$ & 1.0 \\
\hline Sulphur-breasted Bush-Shrike Malaconotus sulfureopectus & 3 & $10.3 \%$ & 1.0 \\
\hline White-bellied Tit Parus albiventris & 2 & $6.9 \%$ & 2.5 \\
\hline Yellow-breasted Apalis Apalis flavida & 2 & $6.9 \%$ & 2.5 \\
\hline Lesser Honeyguide Indicator minor & 2 & $6.9 \%$ & 1.0 \\
\hline Arrow-marked Babbler Turdoides jardineii & 2 & $6.9 \%$ & 4.5 \\
\hline Green-headed Sunbird Deleornis axillaris & 2 & $6.9 \%$ & 1.0 \\
\hline Klaas's Cuckoo Chrysococcyx klaas & 2 & $6.9 \%$ & 1.0 \\
\hline Ashy Flycatcher Muscicapa caerulescens & 2 & $6.9 \%$ & 4.0 \\
\hline African Blue Flycatcher Elminia longicuada & 1 & $3.5 \%$ & 1.0 \\
\hline White-browed (Heuglin's) Robin-chat Cossypha heuglini & 1 & $3.5 \%$ & 1.0 \\
\hline African Pygmy Kingfisher Ispidina picta & 1 & $3.5 \%$ & 1.0 \\
\hline
\end{tabular}


Table 2: Interspecific association (Cole's coefficient of association) of the six most regular participants in mixed-species flocks at Kichwa Tembo. Significant association are shown in bold type.

\begin{tabular}{||l|l|l|l|l|l|l||}
\hline & T. viridis & D. cubla & C. brachyura & P. cabanisi & H. collaris & P. cyanea \\
\hline T. viridis & & $\mathbf{0 . 1 0 3}$ & $-\mathbf{0 . 1 9 0}$ & $\mathbf{0 . 5 7 7}$ & $\mathbf{0 . 2 8 2}$ & $\mathbf{0 . 1 2 8}$ \\
\hline D. cubla & & & $\mathbf{0 . 5 8 4}$ & $\mathbf{0 . 0 7 1}$ & $\mathbf{0 . 2 0 8}$ & $\mathbf{0 . 4 0 3}$ \\
\hline C. brachyura & & & & $\mathbf{0 . 1 7 2}$ & 0.005 & $\mathbf{0 . 3 3 8}$ \\
\hline P. cabanisi & & & & & 0.305 & $\mathbf{0 . 3 1 4}$ \\
\hline H. collaris & & & & & & -0.088 \\
\hline P. cyanea & & & & & \\
\hline
\end{tabular}


Appendix 1: Bird species ranked in order of frequency recorded in 79 ' 15 -species

lists' and the proportion of lists in which present.

\begin{tabular}{|c|c|c|}
\hline Rank & $\begin{array}{r}\text { Species } \\
\end{array}$ & \% Records \\
\hline 1 & Common Bulbul (Pycnonotus barbatus) & 86.1 \\
\hline 2 & African Paradise Flycatcher (Terpsiphone viridis) & 60.8 \\
\hline 3 & White-browed Robin-chat (Cossypha heuglini) & 54.4 \\
\hline 4 & Collard Sunbird (Hedydipna collaris) & 50.6 \\
\hline 5 & Black-backed Puffback (Dryoscopus cubla) & 48.1 \\
\hline 5 & Speckled Mousebird (Colius striatus) & 48.1 \\
\hline 7 & Grey-backed Camaroptera (Camaroptera brachyura) & 44.3 \\
\hline 8 & Black Saw-wing (Psalidoprocne holomelas) & 43.0 \\
\hline 8 & Cinnamon-chested Bee-eater (Merops oreobates) & 43.0 \\
\hline 10 & African Citril (Serinus citrinelloides) & 40.5 \\
\hline 11 & Tawny-flanked Prinia (Prinia subflava) & 39.2 \\
\hline 12 & African Blue Flycatcher (Elminia longicuada) & 36.7 \\
\hline 13 & Northern Black Flycatcher (Melaenornis edolioides) & 35.4 \\
\hline 14 & Yellow-fronted Canary (Serinus mozambicus) & 34.2 \\
\hline 15 & Grey-capped Warbler (Eminia lepida) & 30.4 \\
\hline 16 & Emerald-spotted Wood Dove (Turtur chalcospilos) & 27.9 \\
\hline 17 & Brown-throated Wattle-eye (Platysteira cyanea) & 25.3 \\
\hline 18 & Wire-tailed Swallow (Hirundo smithii) & 24.1 \\
\hline 19 & Purple Grenadier (Uraeginthus ianthinogaster) & 22.8 \\
\hline 19 & Schalow's Turaco (Tauraco schalowi) & 22.8 \\
\hline 19 & Yellow Bishop (Euplectes capensis) & 22.8 \\
\hline 22 & African Pied Wagtail (Motacilla aguimp) & 21.5 \\
\hline 22 & Cabanis's Greenbul (Phyllastrephus cabanisi) & 21.5 \\
\hline 24 & Ring-necked Dove (Streptopelia capicola) & 20.2 \\
\hline 24 & Tropical Boubou (Laniarius aethiopicus) & 20.2 \\
\hline 24 & Yellow White-eye (Zosterops senegalensis) & 20.2 \\
\hline 27 & Brown-crowned Tchagra (Tchagra australis) & 17.7 \\
\hline 28 & Holub's Golden Weaver (Ploceus xanthops) & 16.5 \\
\hline 28 & Marico Sunbird (Cinnyris mariquensis) & 16.5 \\
\hline 28 & Red-rumped Swallow (Hirundo daurica) & 16.5 \\
\hline 28 & White-browed Coucal (Centropus superciliosus) & 16.5 \\
\hline 28 & Yellow-breasted Apalis (Apalis flavida) & 16.5 \\
\hline 33 & Little Bee-eater (Merops pusillus) & 15.2 \\
\hline 33 & Spectacled Weaver (Ploceus ocularis) & 15.2 \\
\hline 33 & Spot-flanked Barbet (Tricholaema lacrymosa) & 15.2 \\
\hline 33 & Winding Cisticola (Cisticola galactotes) & 15.2 \\
\hline 37 & Chin-spot Batis (Batis molitor) & 13.9 \\
\hline 37 & Baglafecht Weaver (Ploceus baglafecht) & 13.9 \\
\hline
\end{tabular}




\begin{tabular}{|c|c|c|}
\hline 39 & Green-headed Sunbird (Deleornis axillaris) & 12.7 \\
\hline 39 & Pale Flycatcher (Bradornis pallidus) & 12.7 \\
\hline 39 & Red-faced Cisticola (Cisticola erythrops) & 12.7 \\
\hline 39 & Stout Cisticola (Cisticola robustus) & 12.7 \\
\hline 39 & Usambiro Barbet (Trachyphonus usambiro) & 12.7 \\
\hline 44 & Blue-spotted Wood Dove (Turtur afer) & 11.4 \\
\hline 44 & Common Waxbill (Estrilda astrild) & 11.4 \\
\hline 44 & Sooty Chat (Myremecocichla nigra) & 11.4 \\
\hline 44 & Yellow-throated Longclaw (Macronyx croceus) & 11.4 \\
\hline 48 & African Moustached Warbler (Melocichla mentalis) & 10.1 \\
\hline 48 & Red-necked Spurfowl (Francolinus afer) & 10.1 \\
\hline 48 & Scaly Francolin (Francolinus squamatus) & 10.1 \\
\hline 51 & Black Cuckoo-shrike (Campephaga flava) & 8.9 \\
\hline 51 & Fork-tailed Drongo (Dicrurus adsimilis) & 8.9 \\
\hline 51 & Olive Sunbird (Cyanomitra olivacea) & 8.9 \\
\hline 51 & Sulphur-breasted Bush-Shrike (Malaconotus sulfureopectus) & 8.9 \\
\hline 55 & African Black-headed Oriole (Oriolus larvatus) & 7.8 \\
\hline 55 & Giant Kingfisher (Megaceryle maxima) & 7.8 \\
\hline 55 & Woodland Kingfisher (Halcyon senegalensis) & 7.8 \\
\hline 58 & African Dusky Flycatcher (Muscicapa adusta) & 6.3 \\
\hline 58 & African Pygmy Kingfisher (Ispidina picta) & 6.3 \\
\hline 58 & Amethyst Sunbird (Chalcomitra amethystina) & 6.3 \\
\hline 58 & Ashy Flycatcher (Muscicapa caerulescens) & 6.3 \\
\hline 58 & Klaas's Cuckoo (Chrysococcyx klaas) & 6.3 \\
\hline 58 & Ross's Turaco (Musophaga rossae) & 6.3 \\
\hline 58 & Tambourine Dove (Turtur tympanistria) & 6.3 \\
\hline 65 & Rattling Cisticola (Cisticola chiniana) & 5.1 \\
\hline 65 & Red-eyed Dove (Streptopelia semitorquata) & 5.1 \\
\hline 65 & Violet-backed Starling (Cinnyricinclus leucogaster) & 5.1 \\
\hline 65 & White-bellied Canary (Serinus dorsostriatus) & 5.1 \\
\hline 65 & Yellow-crowned Canary (Serinus canicollis) & 5.1 \\
\hline 65 & Yellow-rumped Tinkerbird (Pogoniulus bilineatus) & 5.1 \\
\hline 71 & Arrow-marked Babbler (Turdoides jardineii) & 3.8 \\
\hline 71 & Black-and-white-casqued Hornbill (Bycanistes subcylindricus) & 3.8 \\
\hline 71 & Bronze Manikin (Lonchura cucullata) & 3.8 \\
\hline 71 & Brown Parrot (Poicephalus meyeri) & 3.8 \\
\hline 71 & Cardinal Woodpecker (Dendropicos fuscescens) & 3.8 \\
\hline 71 & Crowned Hornbill (Tockus alboterminatus) & 3.8 \\
\hline 71 & Double-toothed Barbet (Lybius bidentatus) & 3.8 \\
\hline 71 & Narina Trogon (Adaloderma narina) & 3.8 \\
\hline 71 & White-bellied Tit (Parus albiventris) & 3.8 \\
\hline 71 & White-browed Scrub Robin (Cercotrichas leucophrys) & 3.8 \\
\hline 71 & White-eyed Slaty Flycatcher (Melaenorinis fischeri) & 3.8 \\
\hline 82 & African Emerald Cuckoo (Chrysococcyx cupreus) & 2.5 \\
\hline 82 & African Goshawk (Accipiter tachiro) & 2.5 \\
\hline 82 & African Green Pigeon (Treron calva) & 2.5 \\
\hline 82 & Bronze Sunbird (Nectarinia kilimensis) & 2.5 \\
\hline 82 & Lemon Dove (Aplopelia larvata) & 2.5 \\
\hline
\end{tabular}




\begin{tabular}{|l|l|c|}
\hline 82 & Lesser Honeyguide (Indicator minor) & 2.5 \\
\hline 82 & Lesser-striped Swallow (Hirundo abyssinica) & 2.5 \\
\hline 82 & Pecroral-patch Cisticola (Cisticola brunnescens) & 2.5 \\
\hline 82 & Red-faced Crombec (Sylvietta ruficapilla) & 2.5 \\
\hline 82 & Siffling Cisticola (Cisticola brachypterus) & 2.5 \\
\hline 82 & Swahili Sparrow (Passer suahelicus) & 2.5 \\
\hline 82 & White-headed Barbet (Lybius leucocephalus) & 2.5 \\
\hline 94 & African Fish Eagle (Haliaeetus vocifer) & 1.3 \\
\hline 94 & Black-headed Heron (Ardea melanocephala) & 1.3 \\
\hline 94 & Brimstone Canary (Serinus sulphuratus) & 1.3 \\
\hline 94 & Broad-tailed Warbler (Schoenicola brevirostris) & 1.3 \\
\hline 94 & Grassland Pipit (Anthus cinnamomeus) & 1.3 \\
\hline 94 & Striated Heron (Butorides striatus) & 1.3 \\
\hline 94 & Green-winged Pytilia (Pytilia melba) & 1.3 \\
\hline 94 & Grey Heron (Ardea cinerea) & 1.3 \\
\hline 94 & Grosbeak Weaver (Amblyospiza albifrons) & 1.3 \\
\hline 94 & Malachite Kingfisher (Alcedo cristata) & 1.3 \\
\hline 94 & Nubian Woodpecker (Campethera nubica) & 1.3 \\
\hline 94 & Red-headed Weaver (Anaplectes rubriceps) & 1.3 \\
\hline 94 & Saddle-billed Stork (Ephippiorhynchus senegalensis) & 1.3 \\
\hline 94 & Scarlet-chested Sunbird (Chalcomitra senegalensis) & 1.3 \\
\hline 94 & Slate-coloured Boubou (Laniarius funebris) & 1.3 \\
\hline 94 & Trilling Cisticola (Cisticola woosnami) & 1.3 \\
\hline 94 & Wooly-necked Stork (Ciconia episcopus) & 1.3 \\
\hline 94 & Yellow-rumped Seedeater (Serinus reichenowi) & 1.3 \\
\hline
\end{tabular}




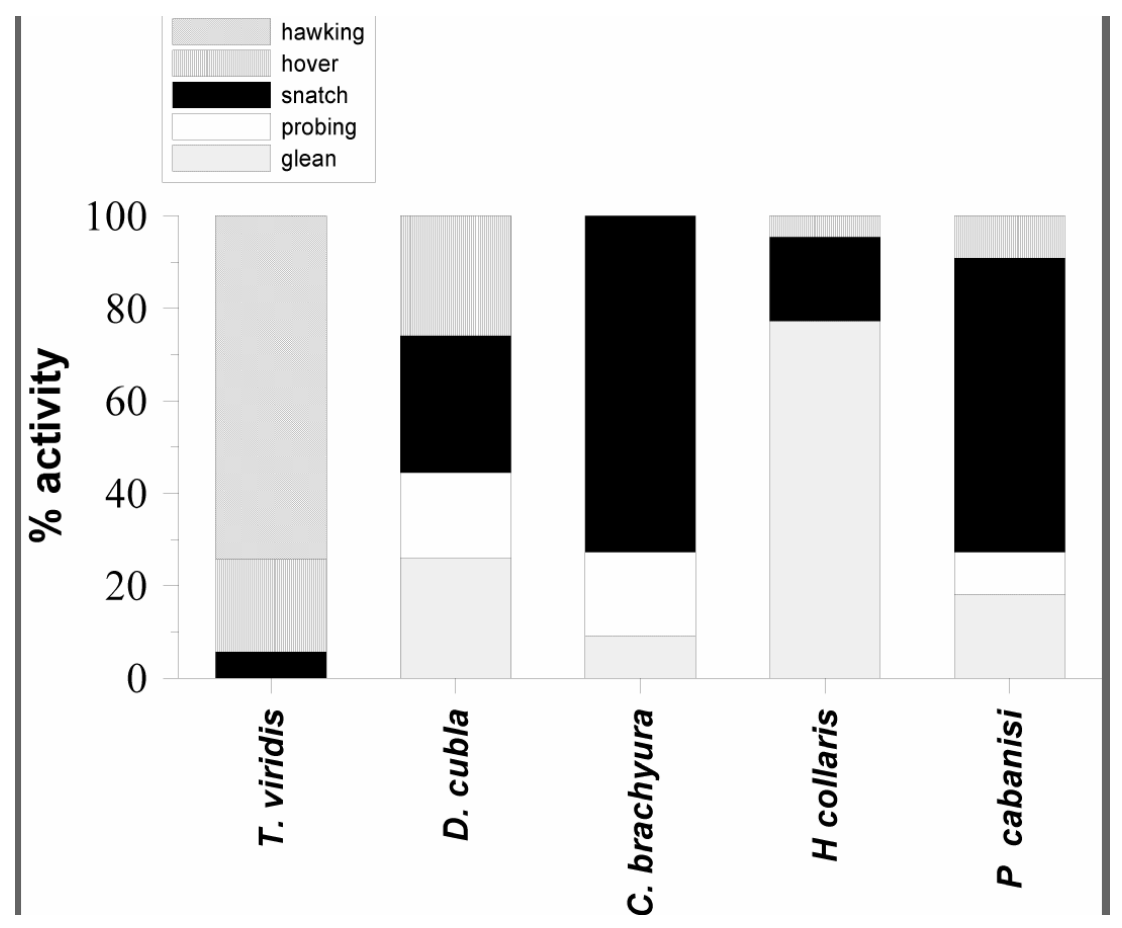

Figure 1: Percentage utilization of different foraging techniques by five species commonly in flocks. 


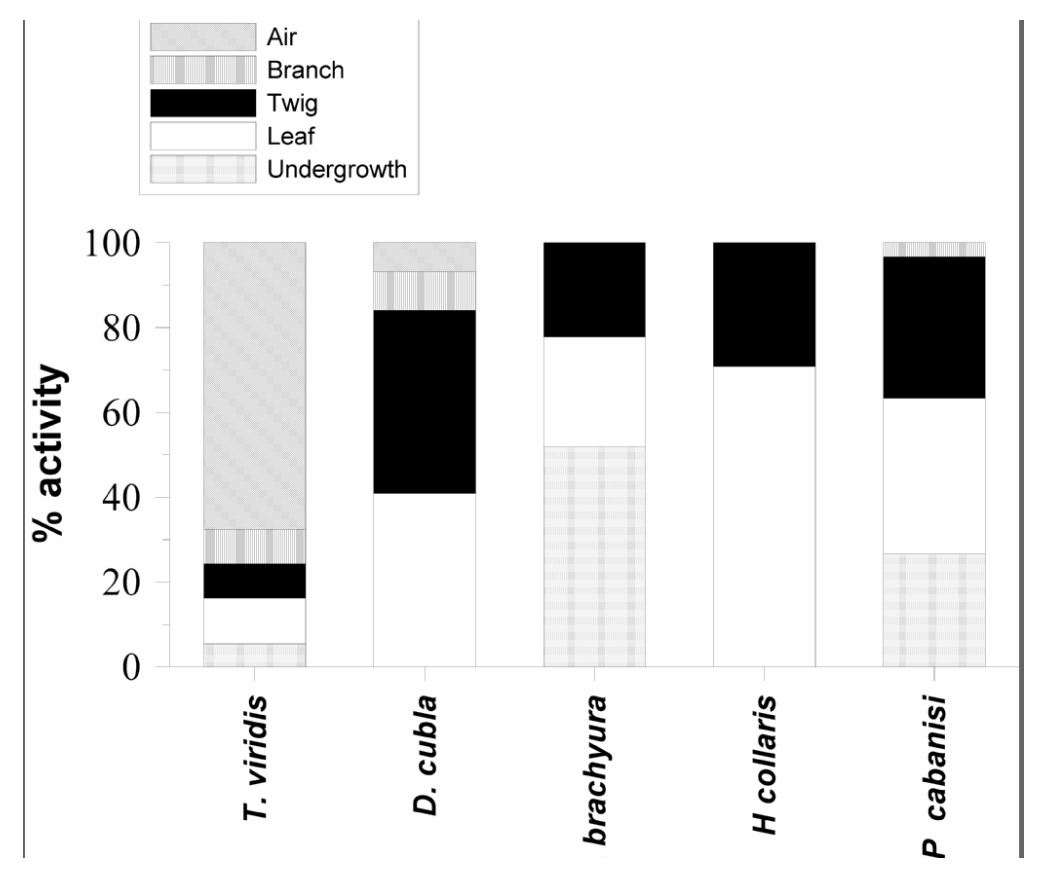

Figure 2: Percentage utilization of different foraging locations by five species commonly in flocks. None of these species were observed foraging on the trunk of trees. 